\title{
Clinical progression of COVID-19 coinfection in people living with the human immunodeficiency virus: scoping review
}

\author{
Curso clínico da coinfecção COVID-19 em pessoas que vivem com o vírus da imunodeficiência humana: scoping review
}

Curso clínico de la coinfección COVID-19 en personas que viven con el virus de la inmunodeficiencia humana: scoping review

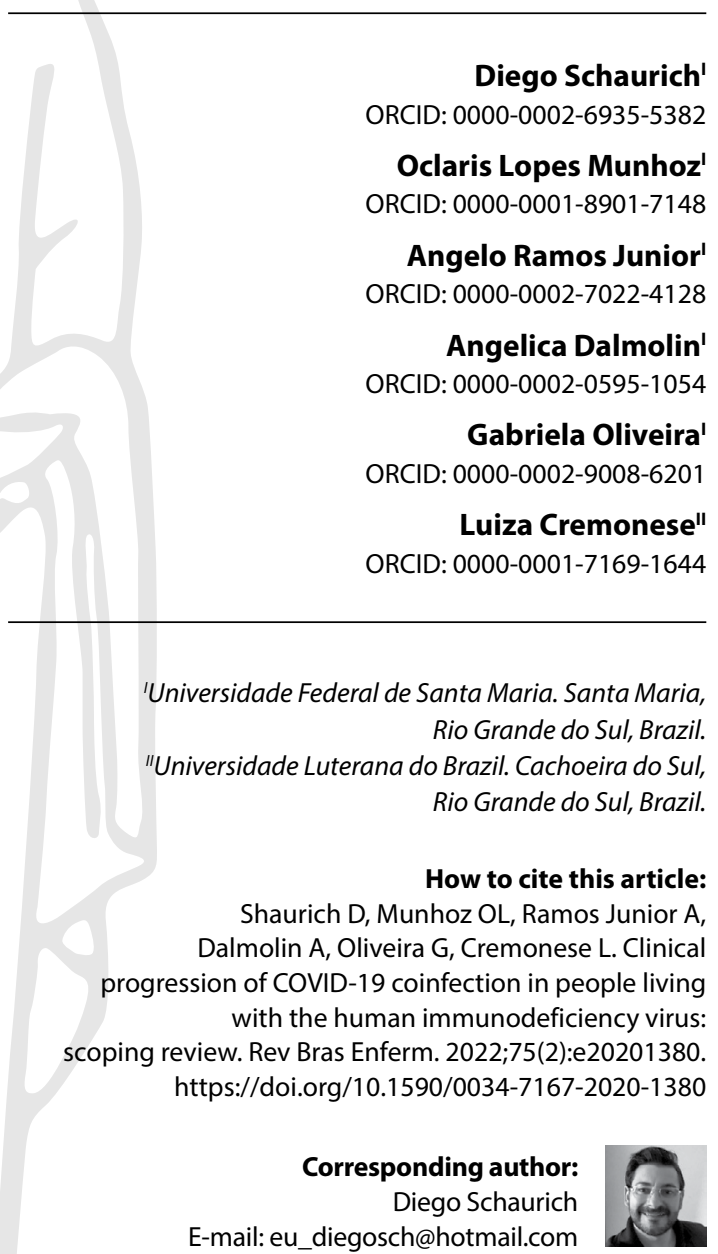

EDITOR IN CHIEF: Dulce Barbosa ASSOCIATE EDITOR: Álvaro Sousa

Submission: $01-19-2021$

\section{ABSTRACT}

Objectives: to map the production of scientific knowledge on the clinical progression of COVID-19 coinfection in people living with the human immunodeficiency virus (HIV). Methods: scoping review, with search strategies in MEDLINE, Scopus, Embase, Web of Science, and LILACS. Dual independent data extraction and analysis of the material with similarity compilation and narrative synthesis. Results: sample consisted of 35 articles. Fever, cough, and dyspnea were the most prevalent signs/symptoms. Recurrent complications involved desaturation/worsening of oxygen desaturation and pneumonia. No standard pharmacological treatment was identified, and the main interventions involved the provision of supplemental oxygen and mechanical ventilation. The studies recommended preventive, care, and pharmacological practices. Conclusions: the clinical manifestations, complications, and treatments/assistance care for people coinfected with SARS CoV-2/HIV are similar to those of the general population. Coinfection, overall, does not infer a worse prognosis. Descriptors: Coronavirus Infections; Pandemics; HIV; Acquired Immunodeficiency Syndrome; Communicable Diseases.

\section{RESUMO}

Objetivos: mapear a produção do conhecimento científico acerca do curso clínico da coinfecção pela COVID-19 em pessoas que vivem com o vírus da imunodeficiência humana (HIV). Métodos: revisão de escopo, com estratégias de busca na MEDLINE, Scopus, Embase, Web of Science e LILACS. Extração dos dados e análise do material de maneira duploindependente, com compilação por similaridade e síntese de forma narrativa. Resultados: amostra constituída de 35 artigos. Febre, tosse e dispneia foram sinais/sintomas mais prevalentes. As complicações recorrentes envolveram dessaturação/piora da dessaturação de oxigênio e pneumonias. Não foi identificado um tratamento farmacológico padrão, e as principais intervenções envolveram oferta de oxigênio suplementar e ventilação mecânica. Os estudos indicaram recomendações de cunho preventivo, assistencial e farmacológico. Conclusões: as manifestações clínicas, as complicações e os tratamentos/cuidados assistenciais às pessoas coinfectadas por SARSCOV-2/HIV assemelham-se aos da população em geral. A coinfecção, via de regra, não indica pior prognóstico.

Descritores: Infecções por Coronavírus; Pandemias; HIV; Síndrome de Imunodeficiência Adquirida; Doenças Transmissíveis.

\section{RESUMEN}

Objetivos: mapear producción del conocimiento científico acerca del curso clínico de la coinfección por COVID-19 en personas que viven con el virus de la inmunodeficiencia humana (VIH). Métodos: revisión de objetivos, con estrategias de búsqueda en la MEDLINE, Scopus, Embase, Web of Science y LILACS. Extracción de los datos y análisis del material de manera duplo-independiente, con compilación por similaridad y síntesis de manera narrativa. Resultados: muestra constituida de 35 artículos. Fiebre, tos y disnea fueron signos/síntomas más predominantes. Las complicaciones recurrentes envolvieron desaturación/peora de la desaturación de oxígeno y neumonías. No ha sido identificado un tratamiento farmacológico estándar, y las principales intervenciones envolvieron oferta de oxígeno suplementario y ventilación mecánica. Los estudios indicaron recomendaciones de cuño preventivo, asistencial y farmacológico. Conclusiones: las manifestaciones clínicas, las complicaciones y los tratamientos/ cuidados asistenciales a las personas coinfectadas por SARS-CoV-2/VIH se asemejan a los de la población en general. La coinfección, vía de regla, no indica peor pronóstico.

Descriptores: Infecciones por Coronavirus; Pandemias; $\mathrm{VIH}$; Síndrome de Inmunodeficiencia Adquirida; Enfermedades Transmisibles. 


\section{INTRODUCTION}

In December 2019, the global scientific community was caught off-guard with the emergence of a high-lethality microorganism, with no specific treatment, and which spread in a peculiar and fast way. Initially detected in the city of Wuhan, Republic of Hubei, China, the virus was identified as SARS-CoV-2 (Severe Acute Respiratory Syndrome Coronavirus 2), of the coronavirus family, which is the etiologic agent of COVID-19, a disease characterized in general symptoms, by fever, cough, sore throat, and dyspnea, with a clinical spectrum that ranges from asymptomatic infections to severe conditions requiring ventilatory support ${ }^{(1)}$.

With this, researchers have strived to understand its forms of transmission and its action and virulence mechanisms, as well as to identify effective pharmacological treatments. The World Health Organization (WHO), then, reacted quickly and, in mid-March 2020, COVID-19 was considered a pandemic, which affects, in a more serious way, specific population groups, such as: the elderly, individuals with chronic diseases (in particular, systemic arterial hypertension - SAH and diabetes mellitus - DM), people living in vulnerable conditions (deprived of freedom, slum/periphery dwellers, etc.), and immunocompromised individuals (under cancer treatment, people living with the virus of human immunodeficiency/acquired immunodeficiency syndrome - HIV/aids etc.) $)^{(2)}$.

Thus, the interest of this review fell on the clinical course (signs and symptoms, laboratory and complementary tests, complications, and interventions) of coinfection by SARS-CoV-2 in people living with HIV/AIDS (PLWHAs). The starting point was Circular Letter No. $8^{(3)}$, issued on March 17, 2020 by the Ministry of Health (MS), containing guidelines for health services specialized in HIV/ AIDS. The document emphasizes the importance that PLWHAs adopt all specific measures to prevent COVID19 (frequent hand hygiene with soap and water or $70 \%$ alcohol-based hand sanitizer, use of mask, home isolation, cleaning and disinfection of objects and surfaces etc.).

Furthermore, this document ${ }^{(3)}$ also signals to state governments the importance of reducing the circulation of this group in health services, by planning, for example, a greater time frame between appointments whenever possible and a three-month period dispensing of antiretroviral therapy (ART). However, to date, there are no MS recommendations regarding assistance to PLWHAs co-infected with the new coronavirus.

This review, therefore, is interested in the developments of the SARS CoV-2/HIV coinfection based on the scientific knowledge produced. In this sense, although national and international efforts are being made to protect and prevent exposure of PLWHAs to the new coronavirus, as well as to treat positive cases, research and scientific evidence ${ }^{(3-4)}$ with indication of effective forms/measures of prevention and health care so that this population is no longer vulnerable to getting sick from COVID-19 and so that the clinical course and complications are no longer serious is still scarce.

\section{OBJECTIVES}

To map the production of scientific knowledge on the clinical progression of COVID-19 coinfection in people living with the human immunodeficiency virus (HIV).

\section{METHODS}

The study was designed as a scoping review, which is used as a tool to map the main concepts that underlie a certain area of knowledge, synthesizing and systematizing the findings in order to contribute to advances in clinical practice. Considering the emergence of the subject in question and the reduced number of scientific evidence on the assistance to PLWHAs co-infected by SARS-CoV-2, this study was chosen due to the possibilities of broadly contemplating the existing scientific literature. To conduct the review, these phases were followed: identification of the guiding question; identification of relevant studies; selection of studies; mapping of information; grouping, summarizing, and reporting of results ${ }^{(5-6)}$.

The mnemonic PCC strategy (Population, Concept and Context) was used, as recommended by the $\mathrm{JBI}^{(6)}$. Thus, the population was people living with HIV/AIDS; the Concept of interest was the COVID-19 pandemic and the SARS-CoV-2 virus; and the Context analyzed was the SARS-CoV-2/HIV coinfection. The review question was defined as: What is the production of scientific knowledge on the clinical progression of COVID-19 coinfection in people living with HIV/AIDS?

The search for articles was carried out on July 30,2020, in the following databases: Medical Literature and Retrieval System Online (MEDLINE), via PubMed; Scopus (Elsevier); Embase (Elsevier); Web of Science (Clarivate); and Literatura Latino-Americana e do Caribe em Ciências da Saúde (LILACS) [Latin American and Caribbean Health Sciences Literature], through the Biblioteca Virtual da Saúde (BVS) [Virtual Health Library]. Access took place via the Portal de periódicos da Coordenação de Aperfeiçoamento de Pessoal de Nível Superior (CAPES) [Coordination for the Improvement of Higher Education Personnel Periodical Portal], via remote access through the Comunidade Acadêmica Federada (CAFe) [Federated Academic Community]. The selection of productions took place in the first half of August 2020, in three stages: in the first research, controlled descriptors appropriate to the consulted databases were used (Medical Subject Headings - MeSH, Emtree, and Descritores em Ciências da Saúde - DeCS [Health Sciences Descriptors]); in the second research, uncontrolled descriptors were used, that is, terms specific to the current topic in all chosen databases and repositories, in order to expand the search; and the third step consisted of identifying and selecting new studies through reference lists of the productions included in this review; however, no further publications were identified in this last phase.

For each search source, a specific strategy was defined, being terms combined with the Boolean operators "AND" and "OR". Thus, the following advanced search strategy was used in the MEDLINE database: $(()(()(()(($ Acquired Immunodeficiency Syndrome[MeSH Terms]) OR (Acquired Immune Deficiency Syndrome[Title/Abstract])) OR (Immuno-Deficiency Syndrome, Acquired[Title/ Abstract])) OR (Syndromes, Acquired Immuno-Deficiency[Title/ Abstract])) OR (Immunodeficiency Syndromes, Acquired[Title/ Abstract])) OR (Syndromes, Acquired Immunodeficiency[Title/ Abstract])) OR (AIDS[Title/Abstract])) OR (Acquired Immunodeficiency Syndrome[Title/Abstract])) OR (HIV Seropositivity[MeSH Terms])) OR (Seropositivities, HIV[Title/Abstract])) OR (AIDS Seropositivities[Title/Abstract])) OR (people living with human 
immunodeficiency virus[Title/Abstract])) OR (people living with HIV/AIDS[Title/Abstract])) AND (((((COVID-19[Title/Abstract]) OR (severe acute respiratory syndrome Coronavirus 2[Title/Abstract])) OR (2019-nCoV[Title/Abstract])) OR (SARSCoV2[Title/Abstract])) OR (2019nCoV[Title/Abstract])) OR (Coronavirus[Title/Abstract])). Based on this aforementioned strategy, the other strategies were adapted according to each databases' specificities.

Studies that specifically addressed the new coronavirus, which causes COVID19, in the context of HIV/AIDS infection and its impact on care for these people were included, regardless of their methodological design. Studies involving children, adolescents, and pregnant women were excluded. Language filters (Portuguese, English, or Spanish) and time frames (December 2019 to July 2020) were applied. This time frame is justified by the possibility of capturing global scientific productions from the first cases of COVID-19(1).

In view of the need to organize references found in the searches, the online software EndNote Web was used. To minimize possible selection biases, the studies were selected by two reviewers, one main reviewer (Reviewer 1) and a secondary reviewer (Reviewer 2). First, titles and abstracts were read, considering the selection criteria, for future full reading. Thus, the reviewers listed the productions independently; and then compared the databases to verify possible divergences, achieving, if necessary, a consensus between the parties. When this did not occur, the third reviewer was consulted.

For data extraction, an adaptation of the form recommended by the JBI was used in order to facilitate the synthesis of information and recommendations ${ }^{(7)}$. The following variables were collected for extraction: publication data (title, month and year, authors, journal, and country of publication); object and/or question and/or study objectives; methodological characteristics (type of study/design; instruments and/or data production techniques; participants and/or sample); and main results (measurement of outcomes and main findings or contributions). Using absolute and relative frequencies, the extracted results were compiled into charts and tables, being discussed descriptively based on classifications of conceptual categories.

To ensure the quality and transparency of this review, the PRISMA ScR checklist ${ }^{(8)}$ was used.

\section{RESULTS}

Through queries in the databases, it was possible to retrieve 1,960 references, and, after applying the filters, 943 remained. Of these, 259 were excluded for duplicity and 649 for not meeting the selection criteria ( 38 being excluded after being read in full). Thus, 35 studies $^{(9-4)}$ made up the final sample, as shown in Figure 1.

The studies in this review were developed mainly in China ( $\mathrm{n}$ $=9$ ) and the United States of America $(n=8)$, followed by Spain $(n=2)$, Italy $(n=2)$, Japan $(n=2)$, United Kingdom $(n=2)$, and Turkey $(n=2)$. The following countries contributed one publication each: South Africa, Germany, Austria, Singapore, El Salvador, India, Republic of Cyprus, and Uganda. There were 34 studies in English and 1 in Spanish, all of which were published in 2020, with the following monthly distribution: 1 in March, 4 in April, 11 in May, 9 in June, 10 in July (2 preprints from August) (Chart 1).

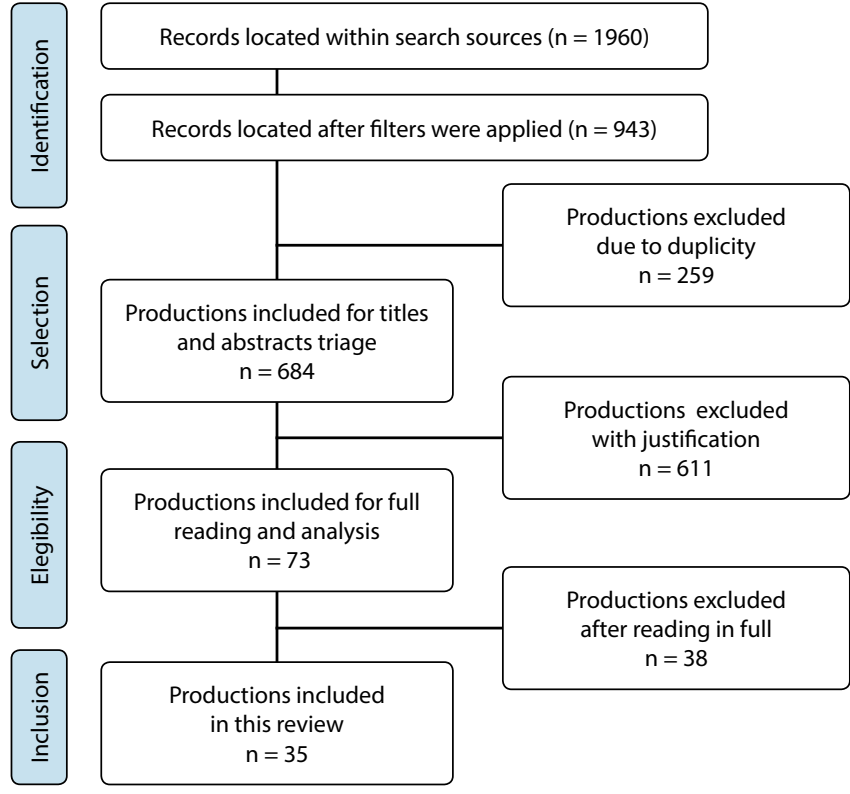

Figure 1 - Reference search and selection flowchart, adapted according to PRISMA ScR ${ }^{(8)}$, Santa Maria, Rio Grande do Sul, Brazil, 2020

Mostly, they were published in specific journals in the areas of infectiology and virology, but also in others such as: cardiology, clinical medicine, pharmacology, and transplants. Concerning the methodological design, the productions were empirical $(n=32)$ and theoretical $(n=3)$, with the following study designs: 28 clinical case reports, 3 retrospective documentary studies, 2 theoretical studies, 1 prospective cohort, and 1 government document (Chart 1).

Of the 35 studies included in this research, 32 were similar in terms of data presentation, which enabled the compilation of findings. Thus, considering them, cases of HIV/SARS-CoV-2 coinfection were reported in 106 people. The other three studies, being theoretical, will be present in the narrative discussion of the findings. Table 1 contains the characteristics related to sex, age group, HIV infection diagnosis period, comorbidities, and length of hospitalization of PLWHAs affected by SARS-CoV-2.

There was a predominance of males ( $n=91 ; 85.8 \%)$, aged between 50 and $59(n=29 ; 27.4 \%)$ and 30 and $39(n=28 ; 26.4$ $\%$ ) years. The predominant period of HIV diagnosis was between 2010 and $2019(n=36 ; 33.4 \%)$. As for comorbidities, patients with SAH $(n=31 ; 29.9 \%)$ and DM $(n=14 ; 13.5 \%)$ stood out, and 26 $(24.5 \%)$ of the 106 patients were previously healthy. Still, among those cases with hospitalization, most remained between 6 to 10 days in the hospital ( $n=21)$; and, for 43 (40.5\%) patients, this information was not included in the analyzed studies.

With regard to antiretroviral therapy (ART), 29 different drug regimens were found, with emphasis on: efavirenz/lamivudine/ tenofovir $(n=10 ; 9.4 \%)$ and elvitegravir/cobicistat/emtricitabine/ tenofovir $(n=9 ; 8.5 \%)$. Furthermore, $8(7.5 \%)$ studies did not refer to ART, and only 7 (6.6\%) PLWHAs did not undergo treatment when co-infected with SARS CoV-2. Of those who maintained adequate treatment, most used ART containing tenofovir ( $n=62 ; 58.5 \%$ ); in addition, 15 (14.2\%) patients used atazanavir, ritonavir, darunavir, and/or lopinavir in their antiretroviral regimen, which are protease inhibitors (PI). Of the 29 drug regimens, in 17 (58.6\%) the patients' ART consisted of three drugs. 
Chart 1 - Scoping review selected studies for analysis, 2020

\begin{tabular}{|c|c|c|c|c|}
\hline Authors & Article title & Periodical title & $\begin{array}{l}\text { Country / } \\
\text { Month in } 2020\end{array}$ & $\begin{array}{l}\text { Design/Type } \\
\text { of production }\end{array}$ \\
\hline Benkovic S, Kim M, Sin $E^{(9)}$ & $\begin{array}{l}4 \text { Cases: HIV and SARS-CoV-2 Coinfection in patients } \\
\text { from Long Island, New York }\end{array}$ & $\begin{array}{l}\text { Journal of Medical } \\
\text { Virology }\end{array}$ & USA / May & $\begin{array}{l}\text { Clinical case } \\
\text { report }\end{array}$ \\
\hline Sun $\sqcup$, Wong SXL, Gollamudi $S^{(10)}$ & $\begin{array}{l}\text { A Case of HIV and SARS-CoV-2 Coinfection in } \\
\text { Singapore }\end{array}$ & $\begin{array}{l}\text { Journal of Acquired } \\
\text { Immune Deficiency } \\
\text { Syndromes }\end{array}$ & $\begin{array}{l}\text { Singapore / } \\
\text { May }\end{array}$ & $\begin{array}{l}\text { Clinical case } \\
\text { report }\end{array}$ \\
\hline $\begin{array}{l}\text { Nakamoto T, Kutsuna S, Yanagawa Y, Kanda } \\
\text { K, Okuhama A, Akiyama Y, et al. }{ }^{(11)}\end{array}$ & $\begin{array}{l}\text { A case of SARS-CoV-2 infection in an untreated HIV } \\
\text { patient in Tokyo, Japan }\end{array}$ & $\begin{array}{l}\text { Journal of Medical } \\
\text { Virology }\end{array}$ & Japan / June & $\begin{array}{l}\text { Clinical case } \\
\text { report }\end{array}$ \\
\hline $\begin{array}{l}\text { Ridgway JP, Farley B, Benoit J-L, Frohne C, } \\
\text { Hazra A, Pettit N, et al. }{ }^{(12)}\end{array}$ & $\begin{array}{l}\text { A Case Series of Five People Living with HIV } \\
\text { Hospitalized with COVID-19 in Chicago, Illinois }\end{array}$ & $\begin{array}{l}\text { AIDS Patient Care and } \\
\text { STDS }\end{array}$ & USA / May & $\begin{array}{l}\text { Retrospective } \\
\text { documentary } \\
\text { research }\end{array}$ \\
\hline $\begin{array}{l}\text { Adachi E, Saito M, Ikeuchi K, Hoshina T, } \\
\text { Yotsuyanagi } \mathrm{H}^{(13)}\end{array}$ & $\begin{array}{l}\text { Cases of coronavirus disease-2019 in HIV-infected } \\
\text { transgender women }\end{array}$ & AIDS & Japan / July & $\begin{array}{l}\text { Clinical case } \\
\text { report }\end{array}$ \\
\hline $\begin{array}{l}\text { Ruan L, Zhang Y, Luo Y, Yu X, Zeng Y, Peng } \\
\text { H, et al. }{ }^{(14)}\end{array}$ & $\begin{array}{l}\text { Clinical features and outcomes of four HIV patients } \\
\text { with COVID-19 in Wuhan, China }\end{array}$ & $\begin{array}{l}\text { Journal of Medical } \\
\text { Virology }\end{array}$ & China / June & $\begin{array}{l}\text { Clinical case } \\
\text { report }\end{array}$ \\
\hline Zhu F, Cao Y, Xu S, Zhou M(15) & $\begin{array}{l}\text { Coinfection of SARS-CoV-2 and HIV in a patient in } \\
\text { Wuhan city, China }\end{array}$ & $\begin{array}{l}\text { Journal of Medical } \\
\text { Virology }\end{array}$ & China / March & $\begin{array}{l}\text { Clinical case } \\
\text { report }\end{array}$ \\
\hline Chen J, Cheng X, Wang R, Zeng X ${ }^{(16)}$ & $\begin{array}{l}\text { Computed Tomography Imaging of an HIV-infected } \\
\text { Patient with Coronavirus Disease } 2019 \text { (COVID-19) }\end{array}$ & $\begin{array}{l}\text { Journal of Medical } \\
\text { Virology }\end{array}$ & China / April & $\begin{array}{l}\text { Clinical case } \\
\text { report }\end{array}$ \\
\hline $\begin{array}{l}\text { Coleman H, Snell LB, Simons R, Douthwaite } \\
\text { ST, Lee MJ }{ }^{(17)}\end{array}$ & $\begin{array}{l}\text { Coronavirus disease } 2019 \text { and Pneumocystis jirovecii } \\
\text { pneumonia: a diagnostic dilemma in HIV }\end{array}$ & AIDS & $\begin{array}{l}\text { United } \\
\text { Kingdom / } \\
\text { July }\end{array}$ & $\begin{array}{l}\text { Clinical case } \\
\text { report }\end{array}$ \\
\hline $\begin{array}{l}\text { Modi AR, Koval CE, Taege AJ, Esfeh JM, } \\
\text { Eghtesad B, Menon KVN, Quintini C, } \\
\text { Miller C(18) }\end{array}$ & $\begin{array}{l}\text { Coronavirus disease } 2019 \text { in an orthotopic } \\
\text { liver transplant recipient living with human } \\
\text { immunodeficiency virus }\end{array}$ & $\begin{array}{l}\text { Transplant Infectious } \\
\text { Disease }\end{array}$ & USA / June & $\begin{array}{l}\text { Clinical case } \\
\text { report }\end{array}$ \\
\hline $\begin{array}{l}\text { Przydzial P, Tchomobe G, Amin K, Engell EA, } \\
\text { Okoh AK }{ }^{(19)}\end{array}$ & COVID-19 crossing paths with AIDS in the homeless & $\begin{array}{l}\text { Journal of Medical } \\
\text { Virology }\end{array}$ & USA / July & $\begin{array}{l}\text { Clinical case } \\
\text { report }\end{array}$ \\
\hline $\begin{array}{l}\text { Toombs JM, den Abbeele KV, Democratis J, } \\
\text { Merricks R, Mandal AKJ, Missouris CG }(20)\end{array}$ & $\begin{array}{l}\text { COVID-19 in } 3 \text { people living with HIV in the United } \\
\text { Kingdom }\end{array}$ & $\begin{array}{l}\text { Journal of Medical } \\
\text { Virology }\end{array}$ & $\begin{array}{l}\text { United } \\
\text { Kingdom / } \\
\text { June }\end{array}$ & $\begin{array}{l}\text { Clinical case } \\
\text { report }\end{array}$ \\
\hline Patel RH, Pella PM(21) & COVID-19 in a patient with HIV infection & $\begin{array}{l}\text { Journal of Medical } \\
\text { Virology }\end{array}$ & USA / May & $\begin{array}{l}\text { Clinical case } \\
\text { report }\end{array}$ \\
\hline $\begin{array}{l}\text { Blanco JL, Ambrosioni J, Garcia F, Martínez } \\
\text { E, Soriano A, Mallolas J, Miro JM(22) }\end{array}$ & COVID-19 in patients with HIV: clinical case series & The Lancet HIV & Spain / May & $\begin{array}{l}\text { Clinical case } \\
\text { report }\end{array}$ \\
\hline $\begin{array}{l}\text { Härter G, Spinner CD, Roider J, Bickel M, } \\
\text { Krznaric I, Grunwald S, et al. }{ }^{(23)}\end{array}$ & $\begin{array}{l}\text { COVID-19 in people living with human } \\
\text { immunodeficiency virus: a case series of } 33 \text { patients }\end{array}$ & Infection & $\begin{array}{l}\text { Germany / } \\
\text { May }\end{array}$ & $\begin{array}{l}\text { Retrospective } \\
\text { documentary } \\
\text { research }\end{array}$ \\
\hline $\begin{array}{l}\text { Riva A, Conti F, Bernacchia D, Pezzati L, } \\
\text { Sollima S, Merli S, et al. }{ }^{(24)}\end{array}$ & $\begin{array}{l}\text { Darunavir does not prevent SARS-CoV-2 infection in } \\
\text { HIV patients }\end{array}$ & $\begin{array}{l}\text { Pharmacological } \\
\text { Research }\end{array}$ & Italy / July & $\begin{array}{l}\text { Clinical case } \\
\text { report }\end{array}$ \\
\hline $\begin{array}{l}\text { Vizcarra P, Pérez-Elías MJ, Quereda C, } \\
\text { Moreno A, Vivancos MJ, Dronda F, et al. }{ }^{(25)}\end{array}$ & $\begin{array}{l}\text { Description of COVID-19 in HIV-infected individuals: } \\
\text { a single-centre, prospective cohort }\end{array}$ & The Lancet HIV & Spain / July & $\begin{array}{l}\text { Prospective } \\
\text { cohort }\end{array}$ \\
\hline $\begin{array}{l}\text { Zhao J, Liao X, Wang H, Wei L, Xing M, Liu } \\
\text { L, et al. }{ }^{(26)}\end{array}$ & $\begin{array}{l}\text { Early virus clearance and delayed antibody response } \\
\text { in a case of COVID-19 with a history of coinfection } \\
\text { with HIV- } 1 \text { and HCV }\end{array}$ & $\begin{array}{l}\text { Clinical Infectious } \\
\text { Diseases }\end{array}$ & China / April & $\begin{array}{l}\text { Clinical case } \\
\text { report }\end{array}$ \\
\hline $\begin{array}{l}\text { Haddad S, Tayyar R, Risch L, Churchill G, } \\
\text { Fares E, Choe M, et al. }{ }^{(27)}\end{array}$ & $\begin{array}{l}\text { Encephalopathy and seizure activity in a COVID-19 } \\
\text { well controlled HIV patient }\end{array}$ & IDCases & USA / May & $\begin{array}{l}\text { Clinical case } \\
\text { report }\end{array}$ \\
\hline El Salvador ${ }^{(28)}$ & $\begin{array}{l}\text { Evidencia disponible acerca de la infección } \\
\text { COVID-19 en pacientes con VIH/SIDA [Available } \\
\text { evidence about COVID-19 infection in HIV/AIDS } \\
\text { patients] }\end{array}$ & $\begin{array}{l}\text { Instituto Nacional } \\
\text { de Salud [National } \\
\text { Institute of Health] }\end{array}$ & $\begin{array}{l}\text { El Salvador / } \\
\text { April }\end{array}$ & $\begin{array}{l}\text { Government } \\
\text { document }\end{array}$ \\
\hline
\end{tabular}


Chart 1 (concluded)

\begin{tabular}{|c|c|c|c|c|}
\hline Authors & Article title & Periodical title & $\begin{array}{l}\text { Country / } \\
\text { Month in } 2020\end{array}$ & $\begin{array}{l}\text { Design/Type } \\
\text { of production }\end{array}$ \\
\hline Bahap M, Kara E, Guven GS & $\begin{array}{l}\text { Fighting on two fronts: drug-drug interactions in } \\
\text { people living with HIV infected with SARS-CoV-2 }\end{array}$ & $\begin{array}{l}\text { European Journal of } \\
\text { Hospital Pharmacy }\end{array}$ & Turkey / June & $\begin{array}{l}\text { Theoretical } \\
\text { study }\end{array}$ \\
\hline Marimuthu J, Kumar BS, Gandhi $\mathrm{A}^{(30)}$ & $\begin{array}{l}\text { HIV and SARS CoV-2 coinfection: A retrospective, } \\
\text { record based, case series from South India }\end{array}$ & $\begin{array}{l}\text { Journal of Medical } \\
\text { Virology }\end{array}$ & India / July & $\begin{array}{l}\text { Retrospective } \\
\text { documentary } \\
\text { research }\end{array}$ \\
\hline $\begin{array}{l}\text { Baluku JB, Mwebaza S, Ingabire G, Nsereko } \\
\text { C, Muwanga } \mathrm{M}^{(31)}\end{array}$ & $\begin{array}{l}\text { HIV and SARS-CoV-2 coinfection: A case report from } \\
\text { Uganda }\end{array}$ & $\begin{array}{l}\text { Journal of Medical } \\
\text { Virology }\end{array}$ & Uganda / May & $\begin{array}{l}\text { Clinical case } \\
\text { report }\end{array}$ \\
\hline $\begin{array}{l}\text { Parker A, Shaw J, Karamchand S, Lahri S, } \\
\text { Schrueder N, Chothia M-Y, et al. }{ }^{(32)}\end{array}$ & $\begin{array}{l}\text { HIV and SARS-CoV- } 2 \text { coinfection: the diagnostic } \\
\text { challenges of dual pandemics }\end{array}$ & $\begin{array}{l}\text { SAMJ: Revista } \\
\text { Médica da África do } \\
\text { Sul [South African } \\
\text { Medical Journal] }\end{array}$ & $\begin{array}{l}\text { South Africa / } \\
\text { June }\end{array}$ & $\begin{array}{l}\text { Clinical case } \\
\text { report }\end{array}$ \\
\hline Aydin OA, Karaosmanoglu HK, Yasar KK ${ }^{(33)}$ & $\begin{array}{l}\text { HIV/SARS-CoV-2 co-infected patients in Istanbul, } \\
\text { Turkey }\end{array}$ & $\begin{array}{l}\text { Journal of Medical } \\
\text { Virology }\end{array}$ & Turkey / April & $\begin{array}{l}\text { Clinical case } \\
\text { report }\end{array}$ \\
\hline Su J, Shen X, Ni Q, Zhao H, Cai J, Zhu B, et al. ${ }^{(34)}$ & $\begin{array}{l}\text { Infection of severe acute respiratory syndrome } \\
\text { coronavirus } 2 \text { in a patient with acquired } \\
\text { immunodeficiency syndrome }\end{array}$ & AIDS & China / July & $\begin{array}{l}\text { Clinical case } \\
\text { report }\end{array}$ \\
\hline Wang $M$, Luo L, Bu H, Xia H(35) & $\begin{array}{l}\text { One case of coronavirus disease } 2019 \text { (COVID-19) } \\
\text { in a patient co-infected by HIV with a low CD4 T-cell } \\
\text { count }\end{array}$ & $\begin{array}{l}\text { International Journal } \\
\text { of Infectious Diseases }\end{array}$ & China / July & $\begin{array}{l}\text { Clinical case } \\
\text { report }\end{array}$ \\
\hline $\begin{array}{l}\text { Guo W, Ming F, Feng Y, Zhang Q, Mo P, Liu } \\
\text { L, et al. } \text {. }^{(36)}\end{array}$ & $\begin{array}{l}\text { Patterns of HIV and SARSCoV- } 2 \text { coinfection in } \\
\text { Wuhan, China }\end{array}$ & $\begin{array}{l}\text { Journal of the } \\
\text { International AIDS } \\
\text { Society }\end{array}$ & China / June & $\begin{array}{l}\text { Clinical case } \\
\text { report }\end{array}$ \\
\hline $\begin{array}{l}\text { Mahmood K, Rashed ER, Oliveros E, Chau } \\
\text { VQ, Hermle T, Jacobs S, et al. }{ }^{(37)}\end{array}$ & $\begin{array}{l}\text { Predisposition or Protection?: COVID-19 in a Patient } \\
\text { on LVAD Support With HIV/AIDS }\end{array}$ & $\begin{array}{l}\text { Journal of the } \\
\text { American College of } \\
\text { Cardiology }\end{array}$ & USA / July & $\begin{array}{l}\text { Clinical case } \\
\text { report }\end{array}$ \\
\hline $\begin{array}{l}\text { Müller H, Kniepeiss D, Stauber R, Schrem H, } \\
\text { Rauter M, Krause R, et al. }{ }^{(38)}\end{array}$ & $\begin{array}{l}\text { Recovery from COVID-19 following hepatitis C, } \\
\text { human immunodeficiency virus infection, and liver } \\
\text { transplantation }\end{array}$ & $\begin{array}{l}\text { American Journal of } \\
\text { Transplantation }\end{array}$ & Austria / June & $\begin{array}{l}\text { Clinical case } \\
\text { report }\end{array}$ \\
\hline Wu Q, Chen T, Zhang $\mathrm{H}^{(39)}$ & $\begin{array}{l}\text { Recovery from COVID-19 in two patients with } \\
\text { coexisted HIV infection }\end{array}$ & $\begin{array}{l}\text { Journal of Medical } \\
\text { Virology }\end{array}$ & China / May & $\begin{array}{l}\text { Clinical case } \\
\text { report }\end{array}$ \\
\hline $\begin{array}{l}\text { Di Giambenedetto S, Del Giacomo P, } \\
\text { Ciccullo A, Porfidia A, De Matteis G, Cianci } \\
\text { R, et al.(40) }\end{array}$ & $\begin{array}{l}\text { SARS-CoV- } 2 \text { infection in a highly experienced } \\
\text { person living with HIV }\end{array}$ & AIDS & Italy / July & $\begin{array}{l}\text { Clinical case } \\
\text { report }\end{array}$ \\
\hline $\begin{array}{l}\text { lordanou S, Koukius D, Matsentidou- } \\
\text { Timiliotou C, Markoulaki D, Raftopoulos V(41) }\end{array}$ & $\begin{array}{l}\text { Severe SARS-CoV-2 pneumonia in a 58-year-old } \\
\text { patient with HIV: a clinical case report from the } \\
\text { Republic of Cyprus }\end{array}$ & $\begin{array}{l}\text { Journal of Medical } \\
\text { Virology }\end{array}$ & $\begin{array}{l}\text { Republic of } \\
\text { Cyprus / May }\end{array}$ & $\begin{array}{l}\text { Clinical case } \\
\text { report }\end{array}$ \\
\hline Li W, Ma Q, Wang X, Tang M, Lin J, Xiao B ${ }^{(42)}$ & $\begin{array}{l}\text { The characteristics of two patients co-infected with } \\
\text { SARS-CoV- } 2 \text { and HIV in Wuhan, China }\end{array}$ & $\begin{array}{l}\text { Journal of Medical } \\
\text { Virology }\end{array}$ & China / June & $\begin{array}{l}\text { Clinical case } \\
\text { report }\end{array}$ \\
\hline Laurence $\mathrm{J}^{(43)}$ & $\begin{array}{l}\text { Why Aren't People Living with HIV at Higher Risk } \\
\text { for Developing Severe Coronavirus Disease } 2019 \\
\text { (COVID-19)? }\end{array}$ & $\begin{array}{l}\text { AIDS PATIENT CARE } \\
\text { and STDs }\end{array}$ & USA / May & $\begin{array}{l}\text { Theoretical } \\
\text { study }\end{array}$ \\
\hline
\end{tabular}

As for the ranges of CD4+ membrane markers, $15(14.2 \%)$ patients had $\leq 200$ cells/mm3; 12 (11.3\%), between 200 and 350; and 15(14.2\%), between 350 and 500 cells $/ \mathrm{mm} 3$. In 50 (47.2\%) patients, the CD4+ was greater than 500; and, for 14 (13.2\%) individuals, this information was not available. Also, 70 (66.0\%) patients had a viral load (VL) below 200 copies; 5 (4.7\%), between 201 and 5,000; and 5 (4.7\%), above 5,000 copies. For 26 (24.5\%) PLWHAs, this data was not informed.

As regards the clinical course of the 15 (14.2\%) patients with CD4+ $\leq 200$ cells $/ \mathrm{mm}^{3}, 2$ (13.3\%) had DM and SAH; 2 (13.3\%), Pneumocystis carinii pneumonia; and 1 (6.7\%) had Kaposi's sarcoma, and 7 (46.7\%) did not use ART. In addition, 14 (93.3\%) had fever, dry cough and/or dyspnea, and most remained hospitalized between five and ten $(n=6 ; 40.0 \%)$ days. Their treatment was based on the use of low-flow oxygen, antibiotic therapy, and corticosteroids, one of which (6.7\%) required high flow therapy; two (13.3\%) with invasive mechanical ventilation; and one (6.7\%), non-invasive. Of the 15,1 (6.7\%) patient died.

Below are the clinical manifestations, treatment, complications, interventions performed, and recommendations for PLWHA coinfected with COVID-19. 
Table 1 - Characteristics related to sex, age group, HIV infection diagnosis period, comorbidities, and length of hospital stay of people living with HIV/ AIDS co-infected with SARS CoV-2, 2020

\begin{tabular}{|c|c|c|}
\hline Variables & $\mathbf{n}$ & $\%$ \\
\hline \multicolumn{3}{|l|}{ Sex } \\
\hline Male & 91 & 85.8 \\
\hline Female & 15 & 14.2 \\
\hline \multicolumn{3}{|l|}{ Age group } \\
\hline 22 to 29 years old & 9 & 8.5 \\
\hline 30 to 39 years old & 28 & 26.4 \\
\hline 40 to 49 years old & 19 & 17.9 \\
\hline 50 to 59 years old & 29 & 27.4 \\
\hline 60 to 69 years old & 17 & 16.0 \\
\hline 70 to 79 years old & 3 & 2.9 \\
\hline$\geq 80$ years old & 1 & 0.9 \\
\hline \multicolumn{3}{|l|}{ HIV diagnosis period } \\
\hline 1985 to 1989 & 3 & 2.9 \\
\hline 1990 to 1999 & 7 & 6.6 \\
\hline 2000 to 2009 & 23 & 21.7 \\
\hline 2010 to 2019 & 36 & 33.4 \\
\hline 2020 & 4 & 3.8 \\
\hline Not reported & 33 & 31.6 \\
\hline \multicolumn{3}{|l|}{ Comorbidities* } \\
\hline Hypertension & 31 & 29.9 \\
\hline Diabetes mellitus & 14 & 13.5 \\
\hline Chronic obstructive bronchopulmonary disorder & 9 & 8.6 \\
\hline Hyperlipidemia & 6 & 5.8 \\
\hline Viral hepatitis & 5 & 4.8 \\
\hline Obesity & 5 & 4.8 \\
\hline Others & 34 & 32.7 \\
\hline \multicolumn{3}{|l|}{ Length of hospitalization ${ }^{\dagger}(n=60)$} \\
\hline 1 to 5 days & 11 & 18.3 \\
\hline 6 to 10 days & 21 & 35.0 \\
\hline 11 to 15 days & 16 & 26.6 \\
\hline 16 to 20 days & 2 & 3.3 \\
\hline 21 to 25 days & 6 & 10.0 \\
\hline$\geq 26$ days & 4 & 6.8 \\
\hline
\end{tabular}

\section{DISCUSSION}

In view of the studied scenario, it was identified that most of the studies originated in China, which is probably related to the fact that SARS-CoV-2 emerged in that country at the end of 2019 , justifying the evidence of the first assistance reports. Then came the United States of America, a country that has one of the largest populations of people living with HIV/AIDS in the world, with well-organized specialized care services, which reacted promptly and scientifically with the dissemination of clinical cases of SARS-CoV-2/HIV coinfection.

When considering the characteristics of PLWHAs infected with the new coronavirus, it is clear that the vast majority of reported clinical cases involved males, which can be explained, among other reasons, by the masculinization movement established in the last decade of the AIDS epidemic, especially among heterosexual men ${ }^{(44)}$. It is worth mentioning the few clinical cases involving females co-infected with SARS CoV-2/HIV ${ }^{(12,20,23-25,30,36)}$, as well as those specific to the female population ${ }^{(31)}$.

Respecting age group, it was observed that $71.7 \%$ of individuals were aged between 30 and 59 years, that is, they were not part of the classic risk group of COVID-19 (aged over 60 years). Furthermore, the studies also identified that the mean age of PLWHAs co-infected with SARS CoV-2 was slightly lower than that of the general population ${ }^{(23,25)}$, and this may have contributed to a better recovery result for co-infected individuals.

The HIV diagnosis period revealed that most individuals knew their seropositivity between 2010 and 2019, followed by those who tested positive in the previous decade (2000-2009). These findings may suggest that such people have routine health care habits (consulting health services, ART administration, diet, etc.)

Chart 2 - Clinical manifestations, treatment, complications, interventions performed, and recommendations for people living with HIV/AIDS co-infected with SARS-CoV-2, 2020

\begin{tabular}{|c|c|}
\hline CLINICAL MANIFESTATIONS & \\
\hline $\begin{array}{l}\text { Signs and symptoms: } \\
\text { - Most prevalent: fever }(n=82 ; 77.4 \%) \text {, cough }(n=76 ; 71.7 \%) \text {, dyspnea }(n=32 ; 30.2 \%) \text {, } \\
\text { fatigue }(n=17 ; 16.0 \%) \text {, headache }(n=15 ; 14.2 \%) \text {, myalgia/arthralgia }(n=15 ; 14.2 \%) \text {. } \\
\text { - Less prevalent: sore throat }(n=10 ; 9.4 \%) \text {, diarrhea }(n=9 ; 8.5 \%) \text {, anosmia }(n=7 ; 6.6 \%) \text {, } \\
\text { chest pain }(n=4 ; 3.8 \%) \text {, vomiting }(n=3 ; 2.8 \%) \text {, dizziness }(n=2 ; 1.9 \%) \text {, tachycardia }(n= \\
2 ; 1.9 \%) \text {, chills }(n=2 ; 1.9 \%) \text {, weakness }(n=2 ; 1.9 \%) \text {, abdominal pain }(n=2 ; 1.9 \%) \text {. } \\
\text { - Rare: ageuusia }(n=1 ; 0.9 \%) \text {, dehydration }(n=1 ; 0.9 \%) \text {, hypoxia }(n=1 ; 0.9 \%) \text {, mental } \\
\text { confusion }(n=1 ; 0.9 \%) \text {. } \\
\text { Asymptomatic: } 5 \text { patients (4.7\%). }\end{array}$ & $\begin{array}{l}\text { Laboratory and imaging tests: } \\
\text { - RT-PCR* positive for SARS-CoV-2. } \\
\text { - Computed tomography and chest radiography with a } \\
\text { ground/opaque glass aspect. } \\
\text { - Lymphopenia. } \\
\text { - High C-reactive protein. } \\
\text { - Thrombocytopenia. } \\
\text { - Elevated Alanine aminotransferase. } \\
\text { - Thrombocytopenia. } \\
\text { - High lactate dehydrogenase. } \\
\text { - Elevated troponin. }\end{array}$ \\
\hline
\end{tabular}

\section{TREATMENTS}

There was no pattern of treatment. However, they were based on maintaining routine ART†; antibiotics; analgesics; anti-inflammatory drugs; corticosteroids; antimalarial/antirheumatic; antifungals; cough suppressants; and vitamin supplements.

\section{COMPLICATIONS}

- Most prevalent: desaturation/worsening of $\mathrm{O} 2$ desaturation $(\mathrm{n}=11 ; 10.4 \%) ;$ fungal/bacterial pneumonias $(\mathrm{n}=8 ; 7.5 \%)$

- Less prevalent: cardiorespiratory arrest $(n=2 ; 1.9 \%)$; leukopenia $(n=2 ; 1.9 \%)$.

- Rare (n= 1; 0.9\%): non-sustained ventricular tachycardia; cardiomegaly without infiltrate; wedge-shaped splenic infarction; maculopapular eruption in lower limbs; acute liver injury; encephalopathy; tonic-chronic seizures; acute respiratory distress syndrome; acute kidney injury; diarrhea; tachypnea; hemoptysis; cranial nerve palsy with ptosis; patient self-inflicted lung injury. 


\section{INTERVENTIONS}

- Supplemental oxygen via nasal cannula and reservoir mask.

- Invasive and non-invasive mechanical ventilation.

- Sedoanalgesia.

- Extracorporeal membrane oxygenation.

- Tracheostomy.

- Vascular Doppler exam.

- Thoracic (computed tomography and radiography) and cardiac (electrocardiogram) imaging exams.

\section{RECOMMENDATIONS}

\section{1) Preventive}

- Uncomplicated cases of SARS-CoV-2/HIV coinfection can be treated through self-isolation at home.

- Home isolation for at least 14 days.

- The use of telemedicine to identify the initial symptoms of COVID-19, for psychosocial support and for coinfection control as a fundamental health care strategy for this population.

- People with advanced or poorly controlled HIV (CD4 <500 $\mathrm{mm}^{3}$ ) and/or with risk factors (over 50 years and presence of comorbidities: diabetes, hypertension, chronic smoking) co-infected with SARS-CoV-2 may have a higher risk of death.

\section{2) Assistance}

- COVID-19 pneumonia in patients with untreated HIV requires careful monitoring, with ART†, of the immune reconstitution inflammatory

syndrome.

- Due to their similar clinical and radiological characteristics, the diagnoses of Pneumocystis jirovecii and COVID-19 pneumonia need to be clarified.

- Individuals co-infected with SARS-CoV-2/HIV can be treated with the same standard care applied to the general population.

- When agitation prevents the safe transport of patients for imaging/testing exams, intubation and sedation should be considered as an option to achieve safer conditions for imaging and diagnostic imaging.

- It is highly recommended to monitor blood drug levels whenever possible in patients co-infected with SARS-CoV-2/HIV.

- Due to the potential for aerosol generation, obtaining an induced sputum sample for Pneumocystis carinii pneumonia testing is currently not recommended.

\section{3) Pharmacological}

- Assess the potential of pharmacological interactions between ART† and treatment for COVID-19 in co-infected people.

- Be aware that co-administration with antiretroviral drugs that inhibit or induce metabolism may increase the concentration of chloroquine or decrease the concentration of hydroxychloroquine.

- Lopinavir/ritonavir may elevate plasma concentrations of chloroquine/hydroxychloroquine and remdesivir, and adverse effects or toxicity are likely to increase.

- The effect of remdesivir may be influenced by strong antiretroviral inhibitors/inducers of metabolism, therefore co-administration is not recommended.

- Early initiation of antimicrobial treatment may translate into a lower risk of opportunistic infections.

- Tenofovir, one of the most widely prescribed anti-HIV drugs for pre-exposure HIV treatment and prophylaxis, blocks the RNA-dependent‡ RNA‡ polymerase critical of SARS-CoV-2.

${ }^{*} R T-P C R$ - Reverse-Transcriptase Polymerase Chain Reaction; ${ }^{\dagger} A R T$ - antiretroviral therapy; ${ }^{*}$ RNA - Ribonucleic acid.

due to concerns about opportunistic infections, also reported in another study ${ }^{(25)}$, and this may have evidenced the quick search for care assistance when the first symptoms of COVID-19 appeared. Another possibility is the advances in the worlds population's health promotion, with the increase in the coverage of rapid tests.

In relation to comorbidities, the most frequent were: $\mathrm{SAH}^{(9,12,14,19-}$ 21,23-25,30,33,36,40), $\mathrm{DM}^{(9,12,14-15,20,23,25,30,33,36-37,39)}$ and chronic obstructive bronchopulmonary disorder ${ }^{(12,23,30,33,36)}$. PLWHAs are more likely to develop other pathologies ${ }^{(4,25)}$, however, their comorbidities are in line with those presented by the general population ${ }^{(2)}$. It is known that SAH and DM are among the previous pathologies that most predispose to complications of COVID-19, and it was noticed that PLWHAs who had such comorbidities also presented worsening of their health condition, since, of the 7 patients co-infected with SARS-CoV-2/HIV who died, 3 had hypertension and/or diabetes.

For the vast majority of PLWHAs co-infected with SARS-CoV-2, the length of hospital stay ranged from 6 to 15 days (61.6\%), in line with another investigation that presented a mean time of 14.8 days $^{(45)}$. Of the total number of hospitalized patients referred to in the studies $(n=60), 10(16.7 \%)$ needed care in the Intensive Care Unit - ICU ${ }^{(12,20,22,24,27,32-33,36,41)}$; two other studies ${ }^{(23,25)}$ also reported patients in the ICU, but did not mention the length of stay, so they were not included in the scope of these hospitalized patients. The large number of hospitalized PLWHAs, even when they presented mild symptoms of COVID-19, may be related to medical safety and protection measures ${ }^{(23)}$.

Regarding ART, it is clear that $87.7 \%$ of PLWHAs used it regularly, which may represent a protective mechanism for the development of more severe symptoms ${ }^{(21,43)}$ of COVID-19, contributing to a faster clinical improvement than that of the general population $^{(6,10)}$ and with a better prognosis ${ }^{(23)}$; however, considering that there is no consensus, these findings need further investigation. Furthermore, it was identified that 62 (58.5\%) patients were using an antiretroviral regimen containing tenofovir - a finding also present in a cohort study ${ }^{(25)}$. This drug had the theoretical ability to interrupt the infection ${ }^{(43,46)}$, since it proved to be effective against SARS-CoV-2 by binding to RNA polymerase, thus preventing the virus from binding to T lymphocytes. As such, it is believed that PLWHAs using tenofovir may supposedly be more protected than the general population ${ }^{(25)}$.

Concerning $\mathrm{CD} 4+$, it was observed that most people co-infected with SARS CoV-2/HIV $(n=65)$ had a value equal to or greater than 350 cells $/ \mathrm{mm}^{3}$, indicating a competent immune system. Some investigations have shown that, even among those most immunocompromised and with low CD4+ counts, COVID-19 has not manifested itself more severely, as this association prevents the development of a cytokine storm ${ }^{(47)}$. However, in this review, the patient with the lowest CD4+ count $\left(13\right.$ cells $\left./ \mathrm{mm}^{3}\right)$ and who was 
not on ART required admission to the ICU and was on mechanical ventilation for having developed other opportunistic infections (pneumonia) along with severe COVID-19(22). Therefore, the CD4+ count is an important marker for monitoring the responses to treatment and the general health conditions of PLWHAs coinfected with SARS-CoV-2.

As for $V L$, it is clear that undetectable conditions and viral suppression ( $\mathrm{VL}<200$ copies) were present in the vast majority of patients co-infected with SARS-CoV-2/HIV, which can also be a good indicator of a better prognosis. Also, it is noteworthy that the patient with the highest VL (1 million copies) had the classic symptoms of COVID-19 (wet cough and fever) and was hospitalized for six days in the ward, as he did not develop major complications from the diseases ${ }^{(20)}$.

When considering the clinical manifestations of PLWHAs with COVID-19, the most prevalent were fever ${ }^{(9-20,22-27,30,32-42)}$, in 82 patients; cough $^{(9-12,14-20,22-25,27,30,32-42)}$, in 76; and dyspnea ${ }^{(12,14,18-20,22-23,25,32-33,36-37,39,42)}$, in 32 patients. These findings also correspond to the primary signs and symptoms of COVID-19 in the general population ${ }^{(2)}$.

All studies indicated the importance of performing the goldstandard test, RT-PCR (Reverse-Transcriptase Polymerase Chain Reaction), for the detection of SARS-CoV-2, requiring its early performance or in the first clinical manifestations. Furthermore, they emphasize that a positive RT-PCR test for COVID-19 helps in the differential diagnosis and clinical-care decision-making. Other very frequent complementary exams were computed tomography (CT) and chest radiography, initially used to detect pulmonary impairment caused by COVID-19 and, thus, speed up the start of treatment when RT-PCR test results are slow to come out, when laboratories exhaust their testing capacity, or even when there's a shortage of kits. It is noteworthy that CT should not be indicated as an isolated exam of choice for diagnosis ${ }^{(48)}$.

Respecting laboratory tests, the most frequent alterations were related to lymphopenia ${ }^{(11,15,32-34,36,39)}$ and high C-reactive protein $^{(11,13,25-26,37)}$. Also reported were elevated lactate dehydrogenase ${ }^{(11,27)}$, elevated alanine aminotransferase ${ }^{(25)}$, elevated troponin $^{(37)}$, thrombocytopenia ${ }^{(25,33)}$, and plateletopenia ${ }^{(32)}$. Preliminary studies ${ }^{(39,49)}$ indicate that HIV-related lymphopenia could protect PLWHAs co-infected with SARS-CoV-2 from more severe clinical manifestations.

When treatments used for COVID-19 are analyzed, a profusion of attempts can be seen. The most recurrent were hydroxychloroqu ine ${ }^{(11-12,18,21-22,24-25,27,31,33,37,40)}$, maintaining the original $\mathrm{ART}^{(10,16,18,20-}$ 22,24,28,30,39,41) , azithromycin ${ }^{(12,19,21-22,25,27,31-33,40-41)}$, oseltamivir ${ }^{(26,33-34,36,39,41)}$, and tocilizumab(14,22,24-25,35,42). Hydroxychloroquine was normally used in association with azithromycin and, even for those patients who were successful in the treatment of COVID-19, its use continues to be questioned by some researchers ${ }^{(18)}$, its co-administration with ART requires follow-up due to toxicity ${ }^{(29)}$, and further study is needed to prove their real risks and/or benefits ${ }^{(31)}$.

The most common complications reported in studies during the hospitalization period were desaturation/worsening in desaturation $^{(9,11-12,19,22,24,33,35-36,40,42)}$ and fungal/bacterial pneumonia ${ }^{(14,19-20,22,26,32)}$. Furthermore, patients co-infected with SARS-CoV-2/HIV presented leukopenia ${ }^{(27,36)}$ and cardiorespiratory arrest ${ }^{(27,33)}$. The most recurrent care interventions were supplemental oxygen via nasal cannula and/or reservoir mask ${ }^{(9,12,14-15,17,19,24,34-35,37-40,42)}$ and mechanical ventilation ${ }^{(20,22-25,36,41)}$. Thus, it is suggested that the best basic treatment consists of oxygen support and control of comorbidities ${ }^{(29)}$.

The recommendations for PLWHAs co-infected with SARS-CoV-2 were synthesized into three groups (preventive, care, and pharmacological) in view of their objectives. Preventive recommendations draw attention to the fact that patients co-infected with SARS-CoV-2/ HIV who have mild symptoms can be treated with self-isolation at home $^{(9)}$; also, the guidelines are for home isolation for at least 14 days for those recently cured of COVID 19(15,18,21). Telemedicine ${ }^{(28)}$ was identified as a strategic resource to be used for the identification of initial signs and symptoms, for monitoring and psychosocial support, and for the control of SARS-CoV-2/HIV coinfection, as well as being suggested for the general population ${ }^{(50)}$.

The care recommendations refer to the need for a clarification in the diagnostic between pneumonia caused by COVID-19 and other pneumonias ${ }^{(17)}$, the need to monitor drug blood levels ${ }^{(29)}$, and sedation of agitated patients for safe transport ${ }^{(27)}$; they also recommend not obtaining sputum samples due to the generation of aerosols ${ }^{(32)}$; and signal that individuals co-infected with SARS-CoV-2/HIV can be treated with the standard care applied to the general population ${ }^{(25)}$.

Pharmacological recommendations suggest that it is necessary to assess the potential for interactions between ART and the different treatments for COVID-19(28). A study reveals an increase or decrease in exposure to chloroquine/hydroxychloroquine in co-administration with $\mathrm{ART}^{(29)}$ and emphasizes that lopinavir/ ritonavir can increase these drugs' plasma concentrations ${ }^{(29)}$. Furthermore, the early use of antimicrobial drugs can result in a lower risk of opportunistic infections ${ }^{(41)}$ and, therefore, reduce the length of hospital stay and complications resulting from SARS-CoV-2/HIV coinfection.

\section{Study limitations}

The study limitations are related to the interpretation and standardization of results from the designs of primary articles in different languages; and the fact that they were written by health professionals from different parts of the world, with different journal norms, cultures, and local guidelines. Also, possible risks of bias may be present because, for the most part, the studies deal with clinical case reports written without a guideline for the presentation of the data and/or resources used. In addition, comparisons were somewhat restricted due to the different clinical epidemiological characteristics and treatments available to PLWHAs in different parts of the world, and the way in which health services are organized impact the lives of these individuals and the care/treatments for SARS-CoV-2/HIV coinfection.

\section{Contributions to the field of Nursing, Health, or Public Policy}

This article mapped the scientific knowledge published about the clinical course of SARS-CoV-2 coinfection in people living with HIV/AIDS and contributed with the following findings: the most prevalent signs and symptoms were fever, cough, and dyspnea; $58.5 \%$ of the patients were using an antiretroviral regimen containing tenofovir, which, in theoretical terms, is a protective factor against SARS-CoV-2; the main complications were desaturation/ 
worsening of oxygen desaturation and pneumonia, as well as the most common interventions included supplemental oxygen and invasive and non-invasive mechanical ventilation; finally, the clinical manifestations, complications, and treatments - with the exception of maintaining the original ART — are similar to those of the general population.

\section{CONCLUSIONS}

Most studies came from China and the United States, and involved investigations with males, aged between 30 and 59 years. Regarding HIV diagnosis, the period between 2010 and 2019 predominated; and, as for ART, most PLWHAs used it regularly. It was identified that most PLWHAs co-infected with SARS-CoV-2 had CD4+ values equal to or greater than 350 cells $/ \mathrm{mm}^{3}$ and VL under undetectable and viral suppression conditions.

With regard to comorbidities, SAH, DM, and chronic obstructive bronchopulmonary disorder prevailed, with a hospital stay length ranging between 6 and 15 days. The main clinical manifestations were fever, cough, and dyspnea. The tests most used for diagnosis and identification of alterations were RT-PCR, computed tomography, and chest radiography. Complications involved desaturation/worsening of oxygen desaturation and pneumonia. A standard for pharmacological treatment was not identified, as different drug classes were used in order to improve the clinical course of the coinfection. The main interventions were supply of supplemental oxygen and invasive and non-invasive mechanical ventilation. Preventive, assistance, and pharmacological care were recommended for people co-infected with SARS-CoV-2/HIV.

In short, the clinical manifestations, main complications, and treatments/assistance care of PLWHAs co-infected with SARSCoV-2 are similar to those of the general population.

It is noteworthy as a knowledge gap that some data from the studies included in the sample were not presented, which limited comparisons. It is suggested, then, that experimental studies be developed comparing and showing the real clinical manifestations and prognoses of PLWHAs co-infected with SARS-CoV-2, as well as studies that explore the real impact of the infection on the lives of these people and the psychological aspects inherent to the SARS CoV-2/HIV coinfection.

\section{REFERENCES}

1. Ortiz-Prado E, Simbaña-Rivera K, Gómez-Barreno L, Rubio-Neira M, Guaman LP, Kyriakidis NC, et al. Clinical, molecular, and epidemiological characterization of the SARS-CoV-2 virus and the coronavirus disease 2019 (COVID-19), a comprehensive literature review. Diagn Microbiol Infect Dis. 2020;98(1):115094. https://doi.org/10.1016/j.diagmicrobio.2020.115094

2. Organização Mundial de Saúde (OMS). Folha informativa sobre COVID-19: doença causada pelo novo coronavírus [Internet]. Brasília, DF: OMS; 2020[cited 2020 Apr 22]. Available from: https://www.paho.org/bra/index.php?option=com_content\&view=article\&id=6101:covid19 \&ltemid=875

3. Ministério da Saúde (BR). O cuidado das pessoas vivendo com HIV/AIDS (PVHIV) no contexto da pandemia da COVID-19. Brasília, DF: Ministério da Saúde; 2020[cited 2020 Apr 7]. Available from: http://azt.aids.gov.br/documentos/Informe\%20n\%C2\%BA\%2007_20\%20-\%20 Anexo_Of.Circ.\%2008_20-\%20Cuidados\%20PVHIV\%20no\%20contexto\%20COVID-19.pdf

4. UNAIDS (BR). O que as pessoas que vivem com HIV precisam saber sobre HIV e COVID-19 [Internet]. Brasília, DF: UNAIDS Brasil; 2020 [cited 2020 Jun 10]. Available from: https://unaids.org.br/2020/04/o-que-as-pessoas-que-vivem-com-hiv-precisam-saber-sobre-hiv-e-covid-19/

5. Arksey H, O'Malley L. Scoping studies: towards a methodological framework. Int J Soc Res Methodol. 2005;8(1):19-32. https://doi. org/10.1080/1364557032000119616

6. Peters MDJ, Godfrey C, McInerney P, Munn Z, Tricco AC, Khalil H. Scoping reviews: 2020 version. In: Aromataris E, Munn Z, editors. JBI manual for evidence synthesis. Adelaide: JBl; 2020[cited 2020 Jun 19]. https://doi.org/10.46658/JBIMES-20-12

7. The Joanna Briggs Institute. Joanna Briggs Institute reviewers' manual: 2015 edition supplement [Internet]. Adelaide: JBI; 2015 [cited 2020 Apr 8]. Available from: https://nursing. Isuhsc.edu/JBI/docs/ReviewersManuals/Scoping-.pdf

8. Tricco AC, Lillie E, Zarin W, O'Brien KK, Colquhoun H, Levac D, et al. PRISMA extension for scoping reviews (PRISMA-ScR): checklist and explanation. Ann Intern Med. 2018;169(7):467-73. https://doi.org/10.7326/M18-0850

9. Benkovic S, Kim M, Sin E. 4 cases: HIV and SARS-CoV-2 co-infection in patients from Long Island, New York. J Med Virol. 2020;92:2338-40. https://doi.org/10.1002/jmv.26029

10. Sun LJ, Wong SXL, Gollamudi S. A case of HIV and SARS-CoV-2 Co-infection in Singapore. J Acquir Immune Defic Syndr. 2020;84(4):e23-e24. https://doi.org/10.1097/QAl.0000000000002401

11. Nakamoto T, Kutsuna S, Yanagawa Y, Kanda K, Okuhama A, Akiyama Y, et al. A case of SARS-CoV-2 infection in an untreated HIV patient in Tokyo, Japan. J Med Virol. 2020;93(1):40-02. https://doi.org/10.1002/jmv.26102

12. Ridgway JP, Farley B, Benoit J-L, Frohne C, Hazra A, Pettit N, et al. A case series of five people living with HIV hospitalized with COVID-19 in Chicago, Illinois. AIDS Patient Care and STDS. 2020;34(8):331-5. https://doi.org/10.1089/apc.2020.0103

13. Adachi E, Saito M, Ikeuchi K, Hoshina T, Yotsuyanagi H. Cases of coronavirus disease-2019 in HIV infected transgender women. AIDS. 2020;34(9):1435-6. https://doi.org/10.1097/QAD.0000000000002573

14. Ruan L, Zhang Y, Luo Y, Yu X, Zeng Y, Peng H, et al. Clinical features and outcomes of four HIV patients with COVID-19 in Wuhan, China. J Med Virol. 2020;93(1):133-6. https://doi.org/10.1002/jmv.26223 
15. Zhu F, Cao Y, Xu S, Zhou M. Co-infection of SARS-CoV-2 and HIV in a patient in Wuhan city, China. J Med Virol. 2020;92(6):529-30. https://doi. org/10.1002/jmv.25732

16. Chen J, Cheng X, Wang R, Zeng X. Computed tomography imaging of an HIV-infected patient with coronavirus disease 2019 (COVID-19). J Med Virol. 2020;92(10):1774-6. https://doi.org/10.1002/jmv.25879

17. Coleman H, Snell LB, Simons R, Douthwaite ST, Lee MJ. Coronavirus disease 2019 and pneumocystis jirovecii pneumonia: a diagnostic dilemma in HIV. AIDS;34(8):1258-60. https://doi.org/10.1097/QAD.0000000000002571

18. Modi AR, Koval CE, Taege AJ, Esfeh JM, Eghtesad B, Menon KVN, et al. Coronavirus disease 2019 in an orthotopic liver transplant recipient living with human immunodeficiency virus. Transpl Infect Dis. 2020;22(5):e13351. https://doi.org/10.1111/tid.13351

19. Przydzial P, Tchomobe G, Amin K, Engell EA, Okoh AK. COVID-19 crossing paths with AIDS in the homeless. J Med Virol. 2021;93(1):155-7. https://doi.org/10.1002/jmv.26255

20. Toombs JM, Van den Abbeele K, Democratis J, Merricks R, Mandal AKJ, Missouris CG. COVID-19 in three people living with HIV in the United Kingdom. J Med Virol. 2020;93(1):107-9. https://doi.org/10.1002/jmv.26178

21. Patel RH, Pella PM. COVID-19 in a patient with HIV infection. J Med Virol. 2020;92(11):2356-7 https://doi.org/10.1002/jmv.26049

22. Blanco JL, Ambrosioni J, Garcia F, Martínez E, Soriano A, Mallolas J, et al. COVID-19 in patients with HIV: clinical case series. Lancet HIV. 2020;7(5):e314-6. https://doi.org/10.1016/S2352-3018(20)30111-9

23. Härter G, Spinner CD, Roider J, Bickel M, Krznaric I, Grunwald S, et al. COVID-19 in people living with human immunodeficiency virus: a case series of 33 patients. Infection. 2020;48(5):681-6. https://doi.org/10.1007/s15010-020-01438-z

24. Riva A, Conti F, Bernacchia D, Pezzati L, Sollima S, Merli S, et al. Darunavir does not prevent SARS-CoV-2 infection in HIV patients. Pharmacol Res. 2020;157:104826. https://doi.org/10.1016/j.phrs.2020.104826

25. Vizcarra P, Pérez-Elías MJ, Quereda C, Moreno A, Vivancos MJ, Dronda F, et al. Description of COVID-19 in HIV-infected individuals: a singlecentre, prospective cohort. Lancet HIV. 2020;7(8):e554-64. https://doi.org/10.1016/S2352-3018(20)30164-8

26. Zhao J, Liao X, Wang H, Wei L, Xing M, Liu L, et al. Early virus clearance and delayed antibody response in a case of COVID-19 with a history of co-infection with HIV-1 and HCV. Clin Infect Dis. 2020;71(16):2233-5. https://doi.org/10.1093/cid/ciaa408

27. Haddad S, Tayyar R, Risch L, Churchill G, Fares E, Choe M, et al. Encephalopathy and seizure activity in a COVID-19 well controlled HIV patient. IDCases 2020;21:e00814. https://doi.org/10.1016/j.idcr.2020.e00814

28. Zelaya S, Gutiérrez M, Castellanos E, Domíngues R. Evidencia disponible acerca de la infección COVID-19 en pacientes con VIH/SIDA [Internet]. San Salvador: Ministerio de Salud; 2020[cited 2020 Jun 7]. Available from: http://docs.bvsalud.org/biblioref/2020/04/1087774/ evidencia-disponible-acerca-de-la-infeccion-covid19-en-pacient_QJOPzkM.pdf

29. Bahap M, Kara E, Guven GS. Fighting on two fronts: drug-drug interactions in people living with HIV infected with SARS-CoV-2. Eur J Hosp Pharm. 2020;2021;28(1):e3. https://doi.org/10.1136/ejhpharm-2020-002390

30. Marimuthu J, Kumar BS, Gandhi AP. HIV and SARS CoV-2 co-infection: a retrospective, record based, case series from South India. J Med Virol. 2020:93(1):163-5. https://doi.org/10.1002/jmv.26271

31. Baluku JB, Mwebaza S, Ingabire G, Nsereko C, Muwanga M. HIV and SARS-CoV-2 co-infection: a case report from Uganda. J Med Virol. 2020;92(11):2351-3. https://doi.org/10.1002/jmv.26044

32. Parker A, Shaw J, Karamchand S, Lahri S, Schrueder N, Chothia M-Y, et al. HIV and SARS-CoV-2 co-infection: the diagnostic challenges of dual pandemics. S Afr Med J. 2020;110(6):473-5. https://doi.org/10.7196/SAMJ.2020.v110i6.14825

33. Aydin OA, Karaosmanoglu HK, Yasar KK. HIV/SARS-CoV-2 coinfected patients in Istanbul, Turkey. J Med Virol. 2020;92(11):2288-90. https:// doi.org/10.1002/jmv.25955

34. Su J, Shen X, Ni Q, Zhao H, Cai J, Zhu B, et al. Infection of severe acute respiratory syndrome coronavirus 2 in a patient with acquired immunodeficiency syndrome. AIDS. 2020;34(10):1575-6. https://doi.org/10.1097/QAD.0000000000002553

35. Wang M, Luo L, Bu H, Xia H. One case of coronavirus disease 2019 (COVID-19) in a patient co-infected by HIV with a low CD4 T-cell count. Int J Infect Dis. 2020;96:148-50. https://doi.org/10.1016/j.jij.2020.04.060

36. Guo W, Ming F, Feng Y, Zhang Q, Mo P, Liu L, et al. Patterns of HIV and SARSCoV-2 co-infection in Wuhan, China. J Int AIDS Soc. 2020;23(7):e25568. https://doi.org/10.1002/jia2.25568

37. Mahmood K, Rashed ER, Oliveros E, Chau VQ, Hermle T, Jacobs S, et al. Predisposition or Protection?: COVID-19 in a patient on LVAD support with HIV/AIDS. JACC Case Rep. 2020;2(9):1337-41. https://doi.org/10.1016/j.jaccas.2020.05.015

38. Müller H, Kniepeiss D, Stauber R, Schrem H, Rauter M, Krause R, et al. Recovery from COVID-19 following hepatitis C, human immunodeficiency virus infection, and liver transplantation. Am J Transplant. 2020;20(11):3255-6. https://doi.org/10.1111/ajt.16107

39. Wu Q, Chen T, Zhang H. Recovery from COVID-19 in two patients with coexisted HIV infection. J Med Virol. 2020;92(11):2325-7. https://doi. org/10.1002/jmv.26006

40. Di Giambenedetto S, Del Giacomo P, Ciccullo A, Porfidia A, De Matteis G, Cianci R, et al. SARS-CoV-2 infection in a highly experienced person living with HIV. AIDS. 2020;34(8):1257-8. https://doi.org/10.1097/QAD.0000000000002572

41. Iordanou S, Koukius D, Matsentidou-Timiliotou C, Markoulaki D, Raftopoulos V. Severe SARS-CoV-2 pneumonia in a 58-year-old patient with HIV: a clinical case report from the Republic of Cyprus. J Med Virol. 2020;92(11):2361-5. https://doi.org/10.1002/jmv.26053 
42. Li W, Ma Q, Wang X, Tang M, Lin J, Xiao B. The characteristics of two patients coinfected with SARS-CoV-2 and HIV in Wuhan, China. J Med Virol. 2020;93(1):85-8. https://doi.org/10.1002/jmv.26155

43. Laurence J. Why aren't people living with HIV at higher risk for developing severe coronavirus disease 2019 (COVID-19)?. AIDS Patient CareSTDS. 2020;34(6):247-8. https://doi.org/10.1089/apc.2020.29005.com

44. Jacques-Aviñó C, Olalla PG, Antelo AG, Quevedo MF, Romaní O, Caylà JA. The theory of masculinity in studies on HIV: a systematic review. Glob Public Health. 2019;14(5):601-20. https://doi.org/10.1080/17441692.2018.1493133

45. Wang R, Pan M, Zhang X, Han M, Fan X, Zhao F, et al. Epidemiological and clinical features of 125 hospitalized patients with COVID-19 in Fuyang, Anhui, China. Int J Infect Dis. 2020;95:421-8. https://doi.org/10.1016/j.jiji.2020.03.070

46. Elfiky AA. Ribavirin, remdesivir, sofosbuvir, galidesivir, and tenofovir against SARS-CoV-2 RNA dependent RNA polymerase (RdRp): a molecular docking study. Life Sci. 2020;253:117592. https://doi.org/10.1016/j.lfs.2020.117592

47. Guo W, Ming F, Dong Y, Zhang Q, Zhang X, Mo P, et al. A survey for COVID-19 among HIV/AIDS patients in two districts of Wuhan, China [preprint]. SSRN. 2020 https://doi.org/10.2139/ssrn.3550029

48. Osterwalder J. COVID-19: More lung pocus and sparing use of stethoscope, chest X-Ray and lung CT. Praxis (Bern 1994). 2020;109(8):583-91. https://doi.org/10.1024/1661-8157/a003512

49. Mascolo S, Romanelli A, Carleo MA, Esposito V. Could HIV infection alter the clinical course of SARS-CoV-2 infection?: when less is better. J Med Virol. 2020;92(10):1777-8. https://doi.org/10.1002/jmv.25881

50. Mann DM, Chen J, Chunara R, Testa PA, Nov O. COVID-19 transforms health care through telemedicine: evidence from the field. J Am Med Inform Assoc. 2020;27(7):1132-5. https://doi.org/10.1093/jamia/ocaa072 